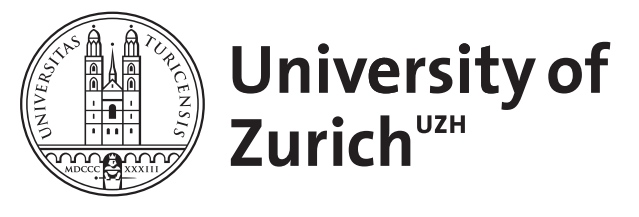

\title{
Newborn screening for inborn errors of metabolism and endocrinopathies: an update
}

\author{
Fingerhut, R ; Olgemöller, B
}

\begin{abstract}
Newborn screening for inborn errors of metabolism and endocrinopathies has expanded during the last two decades, mainly owing to the introduction of new technologies such as tandem mass spectrometry and DNA analysis. However, every expansion of the screening panel requires critical review, discussion, and pilot studies. Different legal regulations and ethical concerns may lead to different decisions. Without claiming to be comprehensive, this review tries to give an overview of newborn screening, including its main problems and target diseases.
\end{abstract}

DOI: https://doi.org/10.1007/s00216-008-2505-y

Posted at the Zurich Open Repository and Archive, University of Zurich ZORA URL: https://doi.org/10.5167/uzh-28588

Journal Article

Published Version

Originally published at:

Fingerhut, R; Olgemöller, B (2009). Newborn screening for inborn errors of metabolism and endocrinopathies: an update. Analytical and Bioanalytical Chemistry, 393(5):1481-1497.

DOI: https://doi.org/10.1007/s00216-008-2505-y 


\title{
Newborn screening for inborn errors of metabolism and endocrinopathies: an update
}

\author{
Ralph Fingerhut $\cdot$ Bernhard Olgemöller
}

Received: 1 July 2008 /Revised: 16 September 2008 / Accepted: 16 October 2008 / Published online: 29 November 2008

(C) Springer-Verlag 2008

\begin{abstract}
Newborn screening for inborn errors of metabolism and endocrinopathies has expanded during the last two decades, mainly owing to the introduction of new technologies such as tandem mass spectrometry and DNA analysis. However, every expansion of the screening panel requires critical review, discussion, and pilot studies. Different legal regulations and ethical concerns may lead to different decisions. Without claiming to be comprehensive, this review tries to give an overview of newborn screening, including its main problems and target diseases.
\end{abstract}

Keywords Newborn screening · Genetic screening · Preventive medicine $\cdot$ Inborn errors of metabolism

$\begin{array}{ll}\text { Abbreviations } \\ \text { 3-MCC } & \text { 3-methylcrotonyl-CoA carboxylase } \\ \text { 17-OHP } & 17 \alpha \text {-hydroxyprogesterone } \\ \text { CAH } & \text { congenital adrenal hyperplasia } \\ \text { CF } & \text { cystic fibrosis } \\ \text { CH } & \text { congenital hypothyroidism } \\ \text { CPT-I } & \text { carnitine palmitoyl transferase I } \\ \text { DBS } & \text { dried blood spots } \\ \text { G6P-DH } & \text { glucose-6-phosphate dehydrogenase } \\ \text { GALT } & \text { galactose-1-phosphate uridyl transferase } \\ \text { IRT } & \text { immunoreactive trypsin } \\ \text { MCAD } & \text { medium-chain acyl-CoA dehydrogenase }\end{array}$

R. Fingerhut $\cdot$ B. Olgemöller

Laboratory Becker, Olgemöller \& Colleagues,

Führichstr. 70,

81671 Munich, Germany

Present address:

R. Fingerhut $(\square)$

University Children's Hospita-Zürich,

Swiss Newborn Screening, Steinwiesstrasse 75,

CH 8032 Zürich, Switzerland

e-mail: ralph.fingerhut@kispi.uzh.ch
MSUD maple sirup urine disease $N$-acetylglutamate synthase

PKU phenylketonuria

RIVM Dutch National Institute for Health and the Environment

TMS tandem mass spectrometry

TSH thyroid stimulating hormone

\section{Introduction}

Screening procedures are primary tools of preventive medicine. Their aim is to detect diseases presymptomatically, or at least in early stages, in order to prevent the outbreak or complications of the disease. A comprehensive definition of screening was published in the first issue of the Journal of Medical Screening [1]: "Screening is the systematic application of a test or enquiry to identify individuals at sufficient risk of a specific disorder to benefit from further investigations or treatment, amongst persons who have not sought medical attention on account of symptoms of that disorder" Screening programs are driven by two different goals. One is an ethical (or Hippocratic) goal, to spare patients the burden of the disease, and the other is a health economic goal, to save money and resources.

In 1968 the World Health Organization published guidelines for including diseases in screening programs, the so-called Wilson and Jungner criteria [2]. The diseases must be treatable, and early treatment should have advantages over later treatment; therefore, the disease should have a sufficient latency or period free of symptoms to allow early intervention. The costs of identifying cases of the disease must be economically justifiable. Although newborn screening should normally be uniformly applied to the whole population, it may be justifiable to screen only a subgroup of the newborn population for a specific disease if the incidence 
in that subgroup is higher than in the rest of the population [3]. This would increase the socioeconomic benefit without reducing the health economic benefit. However, owing to the high mobility of people in the modern world, establishment of subgroups may be difficult or even impossible. In addition, it should be kept in mind that the Wilson and Jungner criteria must be applied to the whole screening procedure; in other words, a disease selection step must be as thoroughly scrutinized as the performance of the laboratory test.

Newborn screening for inborn errors of metabolism and endocrinopathies (performed on dried blood samples) is just one of many screening programs. However, it is of special importance because the benefit for the majority of detected patients, as well as for the health care system and the community, is enormous, especially when calculated on the basis of total lifespan.

\section{History of newborn screening}

Newborn screening effectively started with the development of a rational therapy for phenylketonuria (PKU) by Horst Bickel $[4,5]$ in 1953, and the realization that only patients treated early (presymptomatically) would benefit from therapy [6]. The first PKU screening trials (the diaper test) were based on the fact that patients with PKU excrete large amounts of phenylpyruvic acid in the urine, which can be visualized with Fölling's reagent [7]. However, the sensitivity of this test for neonates was low because phenylpyruvic acid is only excreted when phenylalanine levels in blood exceed $900-1,200 \mu \mathrm{mol} / \mathrm{L}$ [8].

A breakthrough in PKU detection was provided by the bacterial inhibition assay, invented by Robert Guthrie [9] in 1962. With that test, capillary blood, drawn by heel prick and dried on filter paper, the so-called dried blood spots (DBS), became the universal newborn screening specimen; therefore, even today newborn screening is often called the "Guthrie test". However, it is important to note that the basic research of Fölling [7] and Jervis [10, 11] two decades earlier laid the groundwork for this method.

In the following years, similar tests for other metabolic diseases such as maple syrup urine disease (MSUD) [12], homocystinuria [13], histidinemia [14], and galactosemia $[15,16]$ were developed. As screening tests became available for more and more diseases, it became necessary to define criteria for deciding which diseases should be included in newborn screening programs. Fortunately, the Wilson and Jungner criteria [2] are still valid today.

In the 1970s ELISA tests for the determination of thyroid stimulating hormone (TSH) and thyroxine made screening for congenital hypothyroidism $(\mathrm{CH})$ possible [17, 18]. Subsequently other disorders were added to the list, such as biotinidase deficiency [19], congenital adrenal hyperpla- sia $(\mathrm{CAH})$ [20], hemoglobinopathies [21], glucose-6-phosphate dehydrogenase (G6P-DH) deficiency [22], and cystic fibrosis (CF) [23].

The introduction of tandem mass spectrometry (TMS) [24-26] has turned the world of newborn screening upside down, because the paradigm of "one disease-one test" could be abandoned. Now up to 35 diseases can be detected with one test (amino acids and acylcarnitines). Thus, there is now hope that many diseases which were formerly associated with poor outcomes will have a much better prognosis because they can be detected early by newborn screening $[25,27,28]$. Unfortunately, not all new disease screens have been successful; for example, attempts to screen for neuroblastoma in urine [29] did not meet expectations.

\section{Methods for newborn screening}

Newborn screening for inborn errors of metabolism and endocrinopathies is "genetic testing," because if the diagnosis is confirmed clinically after a positive screening result, the cause of the disease in nearly all cases is a genetic defect. Therefore, genetic defects are detected regardless of whether the screening is based on the detection of metabolites (gene products) or on DNA testing [30, 31] (Fig. 1).

Newborn screening can be achieved many ways. The most common is to screen for the biochemical phenotype at the metabolite level, as for PKU, MSUD, organic acidurias, and $\beta$-oxidation defects. A second approach is to screen for the enzymatic phenotype at the protein/enzyme level, as for biotinidase deficiency, classic galactosemia, and G6P-DH. The third approach is to screen for the genotype at the DNA level, as for CF. Each of the three approaches has advantages as well as drawbacks. The screen for galactosemia can serve as an example of these.

Galactosemia screening was initially done at the metabolite level. In the early days of galactosemia screening, total galactose in DBS was estimated with a microbiological

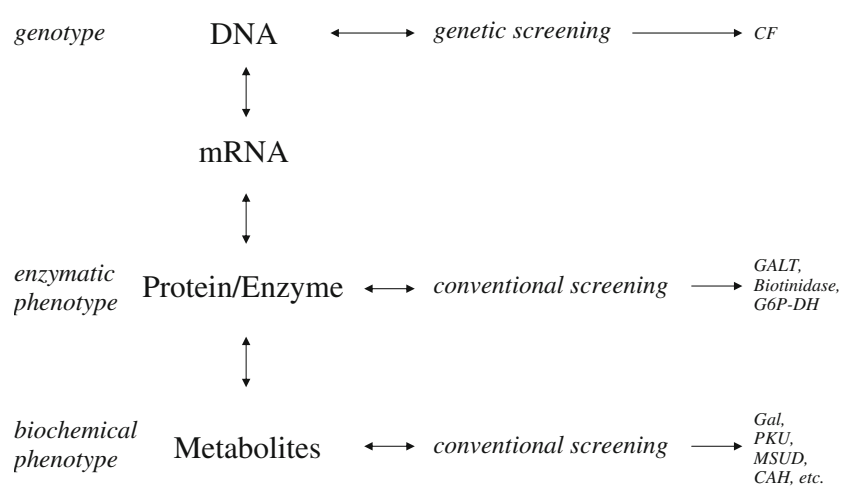

Fig. 1 Detection of genetic defects at different levels. $m R N A$ messenger RNA 
assay [32]. However, a reliable galactosemia test requires patients to ingest exogenous lactose. In contrast to PKU testing, where endogenous catabolism provides enough material to be detected reliably in a routine screen, the endogenous production of galactose (approximately 13$25 \mathrm{mg} / \mathrm{kg}$ per day [33]) is not always enough to reliably detect potential galactosemia patients. Later, quantitative enzymatic galactose assays were used [34] for galactosemia screening, but the problems stayed the same. Then it was thought that the problem could be solved by the introduction of a qualitative assay for galactose-1-phosphate uridyl transferase activity (GALT) [15], which screens for galactosemia on the enzyme level. Nowadays the classical qualitative "Beutler test" has been replaced by a semiquantitative test for GALT [35]. This made galactosemia screening independent of lactose ingestion. Although this increased the sensitivity of the test, it did not improve the specificity, because the measurement of GALT activity detects a lot of newborns with mild enzyme variants, the so-called Duarte variants; these patients do not need treatment [36, 37]. Furthermore, false positives can result if enzyme activity is inactivated by heat or disinfectants. A combination of both tests, measurement of total galactose and GALT activity, can reduce both false positives and the detection rate of Duarte variants. Further improvement requires a two-tier strategy to identify carriers of the Duarte mutations [38], and thereby exclude classic galactosemia.

Two-tier strategies, which use DNA testing as the second step, can also help to significantly reduce the recall rate in other screening tests that suffer low specificity on the metabolite level, such as CF screening [39] and $\mathrm{CAH}$ screening [40]. However, in many countries, whenever DNA testing is performed, legislation mandates informed consent (from either patient or parent) and genetic counseling (if the result is positive). This causes extra expense for the screening organization and may hamper screening workflow.

Newborn screening tests that rely solely on DNA testing are rare and can only be applied to diseases and populations that have a major mutation with a very high frequency such as the $\Delta \mathrm{F} 508$ mutation in CF patients of northern European descent [41]. Therefore, nearly all screens for CF still use the two-tier strategy.

Alternative strategies have been proposed to avoid DNA testing. Early screening programs for CF [42] required a second sample at the age of 6 weeks for immunoreactive trypsin (IRT) if the IRT level was elevated in the first sample. More recently, a combination of IRT and pancreasassociated protein determinations has been described; initial trials have been conducted on this approach [43-45].

Testing can be further improved by using three-tier protocols. The CF screening workflow in the UK combines an IRT/DNA testing strategy for the first sample, then tests a second sample for IRT if the first result does not exclude $\mathrm{CF}$. This protocol results in very low rates of confirmatory sweat tests and unwanted carrier detection.

All methods suitable for newborn screening must have some major features in common: They must support a high throughput, they should be sensitive and specific, and they must be inexpensive. In most countries newborn screening is centralized in regional screening laboratories. In many countries a minimum number of screening samples is recommended, in order to provide testing agencies with sufficient expertise to detect even very rare disorders. In Germany, for example, a minimum of 50,000 newborn screening samples per year is mandatory.

Radioimmunoassay, ELISA, or fluoroimmunoassay tests are available for TSH (CH screening), $17 \alpha$-hydroxyprogesterone (17-OHP; CAH screening), and IRT (CF screening). The use of the AutoDelfia ${ }^{\mathrm{TM}}$ kits is widespread. These kits use time-resolved immunofluorescence with europium(III)labeled antibodies. The AutoDelfia tests are approximately 10 times more sensitive than comparable ELISA tests with, for example, $\beta$-galactosidase-coupled antibodies [46].

The tests for galactosemia, biotinidase deficiency, and tyrosinemia type I (inhibition of the porphobilinogen synthase by succinyl acetone) are photometric or fluorimetric enzyme assays.

Hemoglobinopathies are detected by isoelectric focusing of the hemoglobin chains. This is a labor-intensive test, and large screening laboratories must have many isoelectric focusing apparatuses.

Amino acidemias, organic acidurias, $\beta$-oxidation disorders, and carnitine cycle disorders are detected with TMS. The TMS technique has long been known; it was first described by Thomson [47] in 1909. However, this method only became suitable for high-throughput screening with the advent of multiquadrupole technology, which was introduced by Yost and Enke [48], and electrospray ionization, which was described by Dole et al. [49] and introduced by Yamashita and Fenn [50, 51] in 1984.

The TMS technique will be discussed in detail elsewhere [52]. Briefly, for newborn screening, normally triplequadrupole mass spectrometers are used. In the first quadrupole, selected ions are filtered according to their $\mathrm{m} / \mathrm{z}$ ratio (molecular mass to charge). After collision-induced dissociation in the collision cell (quadrupole 2), specific fragments can be analyzed in the third quadrupole. Amino acids and acylcarnitines are extracted from the DBS with methanol. These can be analyzed either directly or after they have been converted to their butyl esters. Both methods have advantages and disadvantages. Direct analysis is faster, but the butylation method is more sensitive (mean limit of detection/limit of quantitation $0.08 / 0.13 \mu \mathrm{mol} / 1$ for butylated acylcarnitines, and $0.20 / 0.30 \mu \mathrm{mol} / 1$ for underivatized acylcarnitines, respectively). For underivatized metabolites, 
analysis requires choosing a specific pair of ions, one from the first quadrupole and one from the third quadrupole. For the butylated amino acid a neutral loss of 102 is characteristic; for the butylated acylcarnitines, a product ion of $m / z=85$ is characteristic.

\section{Age at sampling for newborn screening}

Most screening programs are based on a single sample taken at a certain recommended age. There are only a few programs, for example, in Texas [53], that test a second sample from all newborns.

Unfortunately, different diagnostic indicators appear at different ages. Enzyme activities (e.g., biotinidase, GALT, G6P-DH) are not influenced by the age of the child. However, many metabolite levels are age-dependent. For example, TSH and especially 17-OHP levels increase during delivery, but normalize quickly within the first $24 \mathrm{~h}$. Other metabolites, such as amino acids that are transported across the placenta, will increase with time in affected patients. The velocity of this increase depends on the magnitude of the enzyme defect. Acylcarnitines do not seem to be transported across the placenta; therefore, their levels are already elevated at birth.

Thus, the age at which blood is collected for newborn screening is always a compromise. In general, it is desirable to detect patients as early as possible to allow sufficient time for intervention prior to the onset of symptoms. For example, early screening is crucial for disorders such as MSUD, propionic acidemia, and methylmalonic acidemia, in which symptoms appear during the second week of life. If screening is not early enough, patients may suffer lifethreatening metabolic decompensation. On the other hand, early screening may decrease sensitivity and specificity.

Blood collection during the first $24 \mathrm{~h}$ of life would result in high recall rates for $\mathrm{CH}$ and $\mathrm{CAH}$. PKU and MSUD can be detected after approximately $8 \mathrm{~h}$ of life, while methionine in homocystinuria might only be increased after the fifth day of life. Organic acidemias can be detected from birth, and fatty acid oxidation defects are best detected when the babies are maximally catabolic. So what is the optimal time point for blood collection for newborn screening?

In Germany the recommended time for blood sampling is between 36 and $72 \mathrm{~h}$ of life. This guideline takes the abovementioned arguments into account. However, another important factor in determining sampling time is that the majority of mothers will leave the hospital during that 36-72-h time frame. Thus, that time frame was chosen to ensure sampling at the place of birth, which is desirable in order not to lose track of patients. In summary, the standard practices of health-care facilities will also influence the choice of sampling age; these practices may be different in different countries.

\section{Target diseases}

An overview of the diseases listed below is given in Table 1 . Target diseases differ with respect to their relevance ranking and their inclusion in screening programs.

\section{High relevance ranking, included in most programs}

\section{Endocrinopathies}

\section{Congenital hypothyroidism}

The worldwide incidence of primary $\mathrm{CH}$ is approximately 1:4,000. The majority of cases are due to sporadic dysplasia of the thyroid. Only $10-20 \%$ of the cases are due to genetically determined deficiencies of peroxidase or deiodinase. The first clinical signs of $\mathrm{CH}$ are rather nonspecific, such as prolonged icterus and failure to thrive. Early detection (by newborn screening) and treatment will lead to normal development of patients with primary $\mathrm{CH}$; delayed treatment will result in psychomotor and mental retardation. The screening method of choice is determination of TSH. Secondary CH (TSH deficiency) will not be detected by TSH screening. However, the incidence of TSH deficiency is low $(1: 40,000-1: 90,000)$, and those patients who were detected owing to their short stature did not showed mental retardation [150].

\section{Congenital adrenal hyperplasia}

CAH can be caused by several enzyme deficiencies (steroid-21-hydroxylase, 11 $\beta$-hydroxylase, $3 \beta$-hydroxysteroid dehydrogenase, $17 \alpha$-hydroxylase, 20-lyase, and cholesterol desmolase). Deficiency of steroid-21-hydroxylase is the most frequent and clinically most important cause [151]. The worldwide incidence is approximately $1: 14,000$ [152]. The condition has a broad spectrum of clinical presentation, ranging from salt wasting through simple virilizing to nonclassic forms. Screening programs that use a single sample taken shortly after birth may only be sensitive enough to detect the salt-wasting forms. About $61 \%$ of simple virilizing and $87 \%$ of nonclassic forms can only be detected through a second screen at around 12 weeks of age [53, 113]. CAH screening also has additional problems. 17-OHP levels are highly variable owing to neonatal stress and the cross-reactivity of widely used ELISA tests with steroid sulfates. This variability increases the rate of false positives, especially in premature and critically ill infants. Many published studies have tried to avoid unnecessary controls by adjusting cut-off levels to gestational age [153], birth weight [154], birth weight and age [155]. Other approaches have involved introducing a 


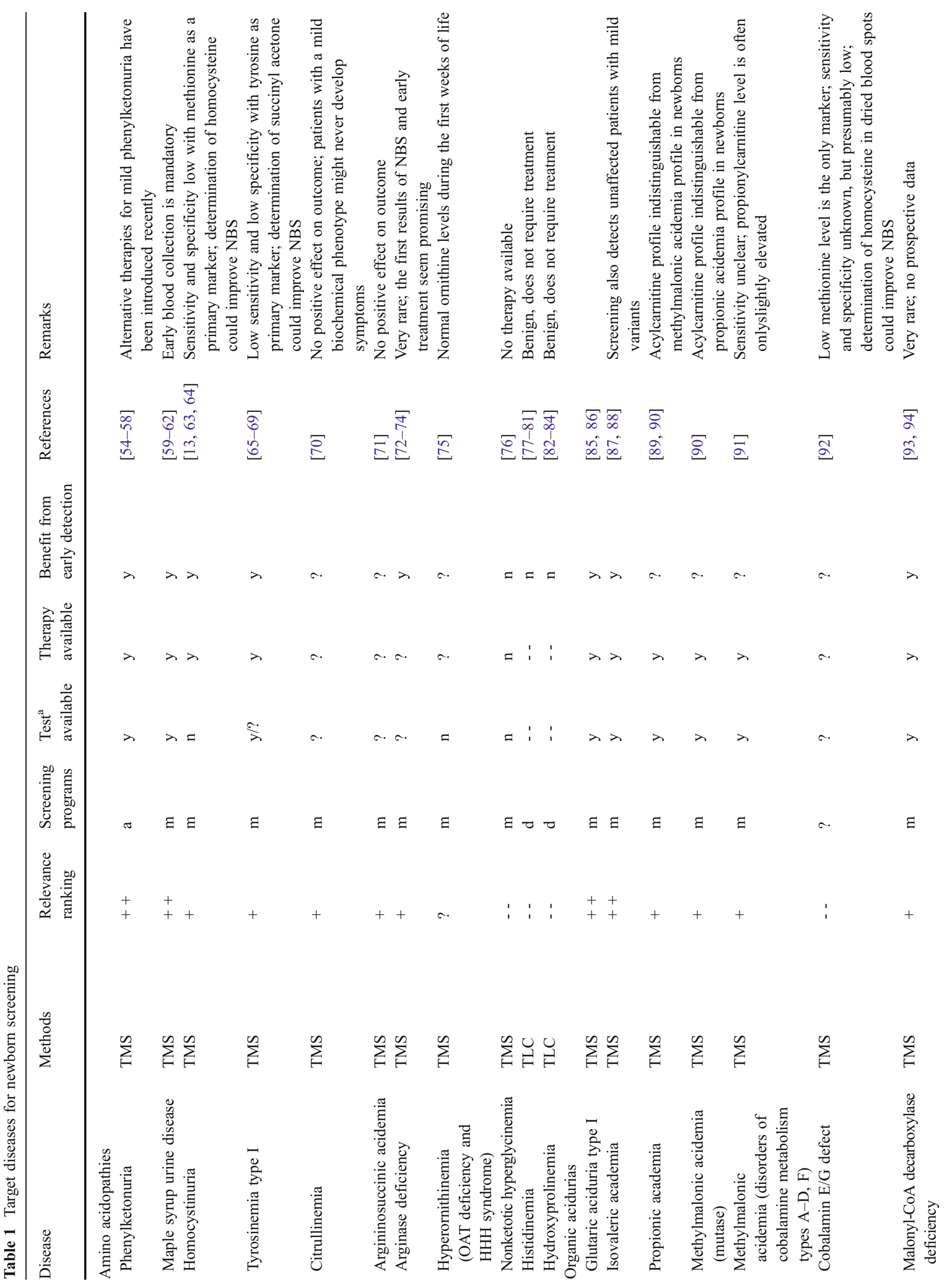




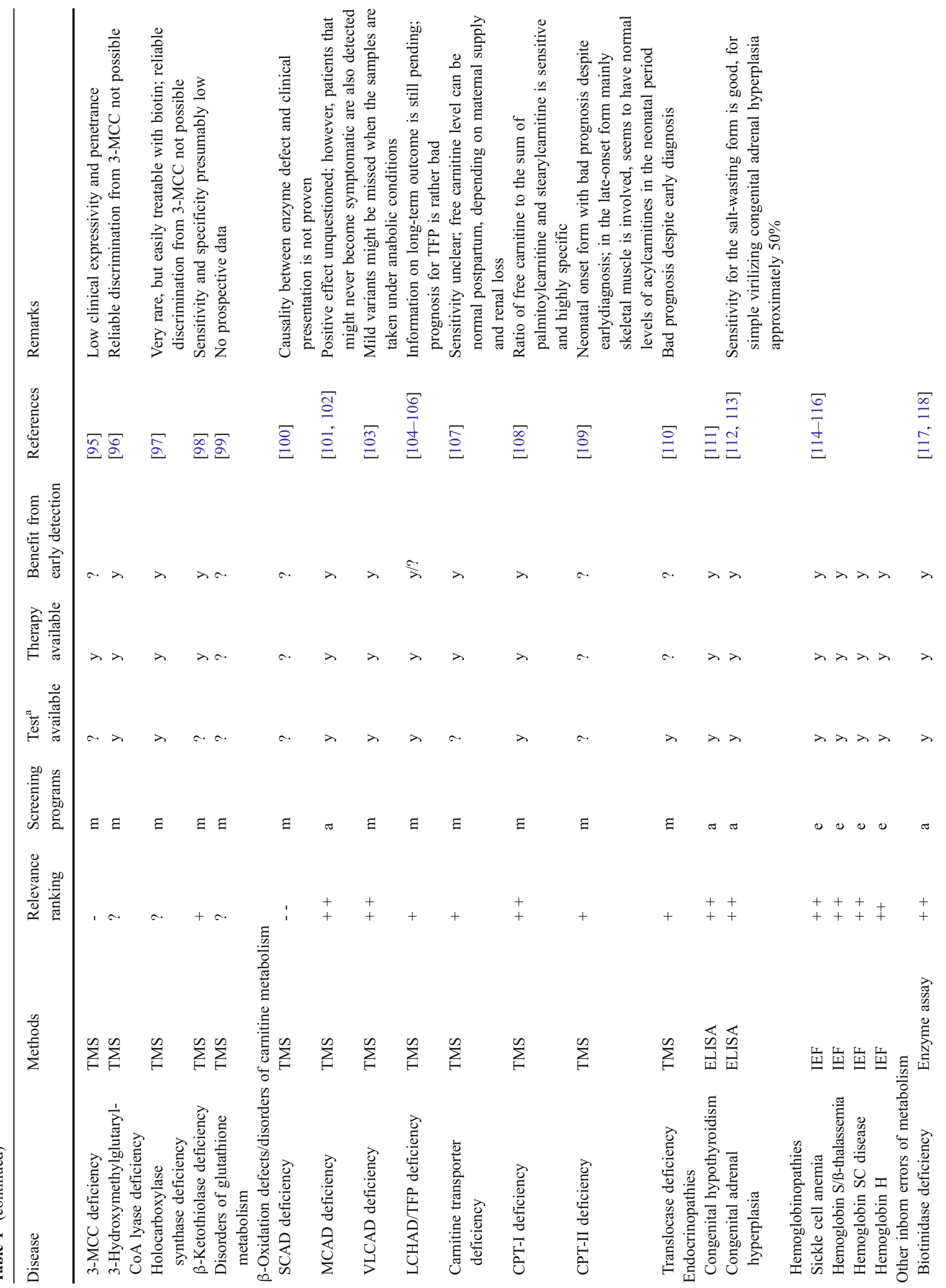




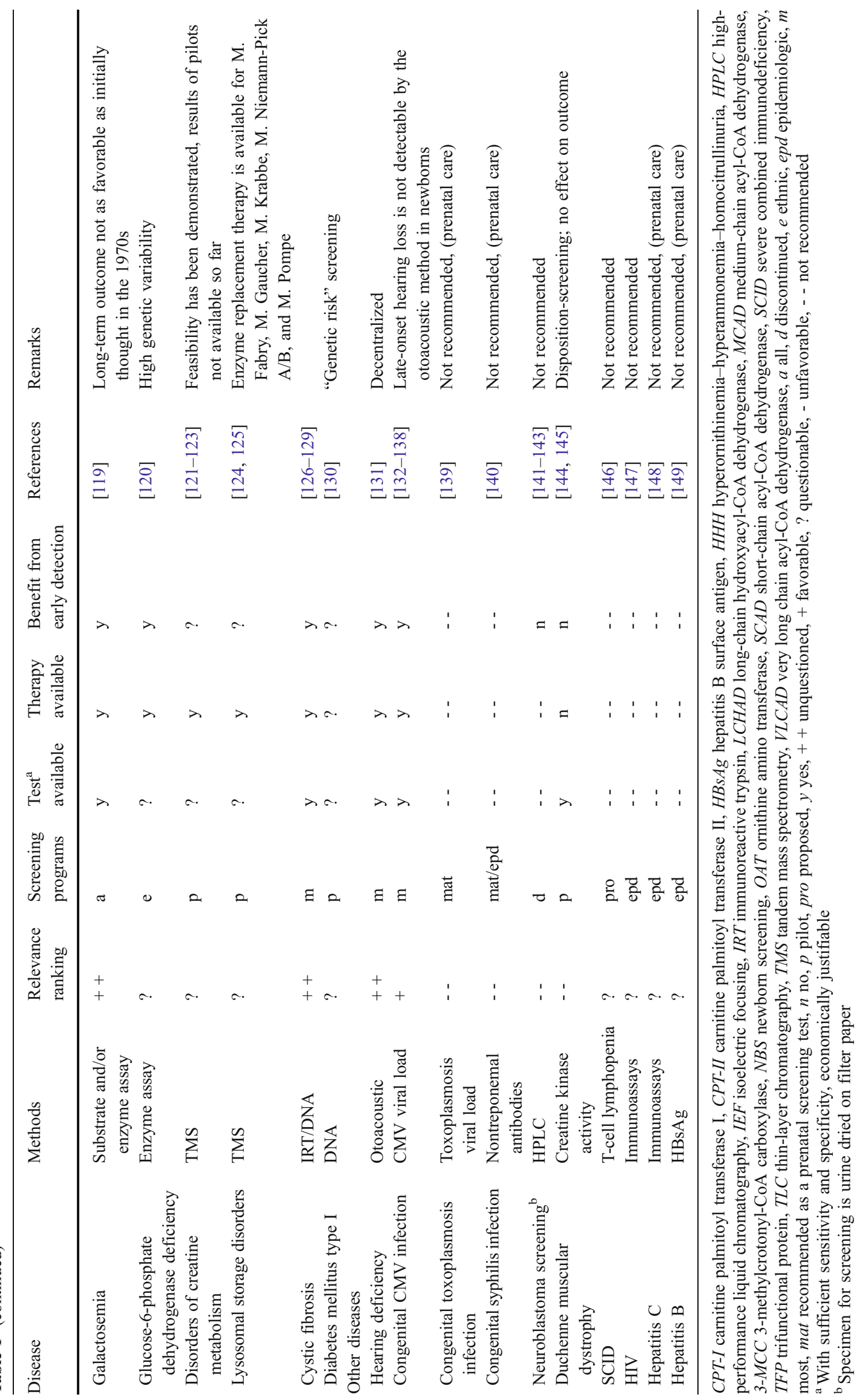


second-tier test, either with TMS $[156,157]$ or molecular genetic analysis [40].

Amino acidopathies

\section{PKU and MSUD}

Classic PKU results from a defect of phenylalanine hydroxylase. Phenylalanine hydroxylase converts phenylalanine to tyrosine, with tetrahydrobiopterin as a cofactor. In untreated patients, phenylalanine accumulates and is converted to toxic phenylpyruvate. During the first months of life, PKU patients seem to develop normally. The first clinical signs are vomiting, failure to thrive, and, later, severe mental retardation, epilepsy, dysmyelination (or demyelination) in the brain, and a mousy odor of the urine (due to the excretion of phenylpyruvic acid). The incidence of PKU is 1:11,000. Hyperphenylalaninemia, characterized by phenylalanine hydroxylase activities of about 3-10\%, does not require treatment (incidence 1:10,000). Atypical PKU, due to a defect in tetrahydrobiopterin metabolism, is generally very rare; however, the incidence is higher in East Asia [158].

MSUD is caused by a defect of the branched-chain oxo acid dehydrogenase complex. Reports on the total incidence have arrived at quite different numbers. Apart from special populations such as the Mennonites from Pennsylvania with an incidence of 1:358 [159], the overall incidence was estimated to be around 1:245,000 in the USA [12]. Collaborative data from Europe reported a total incidence of about $1: 120,000$ [160], and results from the Bavarian screening program from 1999 to $2008(1: 115,000)$ support these data. Since amino acids are transported through the placenta, levels of phenylalanine and branched-chain amino acids are normal at birth in neonates with PKU and MSUD, respectively. Concentrations in blood rise postpartum. In individual cases of PKU, increased phenylalanine levels were reported just $6 \mathrm{~h}$ after birth [161]. Elevations of the levels of branchedchain amino acids have been observed in MSUD $24 \mathrm{~h}$ after birth $[162,163]$. Glucose infusion during the first day of life without enteric nutrition may prevent protein breakdown and is a possible cause of false-negative screening results [164]. Early intervention in MSUD is crucial to avoid severe metabolic decompensation, which may lead to coma (or death) or may require extracorporal detoxification [61].

Organic acidurias

\section{Glutaric aciduria type I}

Glutaric aciduria type I (glutaryl-CoA dehydrogenase deficiency) is a defect of leucine catabolism. The overall incidence of glutaric aciduria type $I$ is around 1:85,000 [165]. Untreated patients show normal development during the first weeks or months of life. The first manifestations, often triggered by febrile illness, are dystonia and extrapyramidal movement disorders. Early detection of patients by newborn screening, followed by prevention of the encephalopatic crisis, are a promising approach to ensuring normal development. Newborn screening for glutaric aciduria type I bears the risk of false-negative results when the first screening sample is taken rather late (after the seventh day of life) or when only a second DBS for acylcarnitines is taken after a positive screening result [166]. Extensive guidelines for diagnosis and management have been published [167]. They recommend the analysis of organic acids in urine as a confirmatory test. However, in some low excreters or nonexcreters, this confirmatory test might give a normal result, and hence a false-negative result is possible [168, 169]. In our experience, administering an additional "diagnostic" carnitine load over 2 days improves screening sensitivity. After the carnitine load, glutaryl carnitine levels in affected patients are increased around sevenfold to eightfold.

\section{Isovaleric acidemia}

Isovaleric acidemia (isovaleryl-CoA dehydrogenase deficiency) is a defect in the catabolic pathway of leucine; the incidence is $1: 75,000$. Patients with the acute form of isovaleric acidemia present clinically within the first days of life with poor feeding, vomiting, and lethargy. Patients with the chronic intermittent form develop similar symptoms, but the age of onset is later. The marker metabolite in DBS is isovaleryl carnitine. Newborn screening for isovaleric acidemia has also detected milder variants, which will probably stay symptom-free without any treatment [170]. In addition, TMS cannot distinguish isovaleryl carnitine from 2-methylbutyryl carnitine, which means the screen also detects 2methyl butyryl-CoA dehydrogenase deficiency, presumably a benign condition [171, 172].

$\beta$-Oxidation and carnitine cycle defects

\section{Medium-chain acyl-CoA dehydrogenase deficiency}

Medium-chain acyl-CoA dehydrogenase (MCAD) deficiency is the most prevalent of the $\beta$-oxidation and carnitine cycle disorders, with an incidence of 1:10,000. The first clinical manifestation is vomiting and lethargy, progressing to coma and death if left untreated. These periods are normally preceded by viral infection in the gastrointestinal or upper respiratory tract. The mortality rate in undiagnosed MCAD cases is $20-25 \%$ [173].

Fasting hypoglycemia with low or absent ketone bodies is the leading symptom for all disorders affecting the mitochondrial $\beta$-oxidation pathway. Early diagnosis unquestionably improves the prognosis for MCAD deficiency, although 
newborn screening also detects (biochemically) affected newborns (mild variants with MCAD activities of 10-20\% of normal [174]) that might never develop clinical symptoms.

\section{Other $\beta$-oxidation and carnitine cycle defects}

For the defects affecting the $\beta$-oxidation of long-chain fatty acid, namely, deficiencies in carnitine acylcarnitine translocase and carnitine palmitoyl transferase II, the prognosis, even after early detection, is not so promising. For the very long chain acyl-CoA dehydrogenase and long-chain hydroxyacyl-CoA dehydrogenase deficiencies, there seem to be different forms that show either neonatal (severe forms) or later onset (milder forms). However, owing to the low incidence of these disorders, there are currently too few data available to reach a final decision about including these disorders in screening programs.

However, for the carnitine palmitoyl transferase I (CPT-I) and multiple acyl-CoA dehydrogenase deficiencies, the situation is different. Newborn screening for CPT-I deficiency is highly sensitive and specific, and a rational therapy is available [108]. For multiple acyl-CoA dehydrogenase deficiency a promising therapeutic approach with butyrate supplementation (e.g., ketone bodies as an energy source) is available [175].

All $\beta$-oxidation and carnitine cycle disorders produce specific acylcarnitine profiles in TMS analysis.

Other disorders

\section{Biotinidase deficiency}

Biotinidase is an enzyme that releases biotin from biocytin, which is formed by proteolytic degradation of biotincontaining carboxylases. Two forms of biotinidase deficiency are known, profound and partial biotinidase deficiency, with less than $10 \%$ and $10-30 \%$ residual activity, respectively. The overall incidence is around 1:120,000. Clinical signs may develop as early as the first week of life or up to 10 years of age. Mainly the central nervous system and the skin are affected [176]. Late-diagnosed patients often develop psychomotor retardation, hearing loss, optic atrophy, skin lesions, and hair loss, which may be irreversible. Therapy consists of biotin substitution. The enzyme activity is measured photometrically or fluorimetrically in newborn screening.

\section{Galactosemia}

Three different forms of galactosemia are known: GALT deficiency, with an incidence of 1:72,000, galactokinase deficiency, with an incidence of 1:250,000, and the very rare galactose-4'-epimerase deficiency [177]. GALT deficiency (classic galactosemia) will lead to life-threatening illness within the first weeks of life, with vomiting, jaundice, hepatomegaly, lethargy, hypotonia, and disturbance of blood clotting. Patients with galactokinase deficiency mainly present with bilateral cataracts. Galactose-4'-epimerase deficiency can be expressed either solely in red blood cells, which causes no symptoms, or in all cells and organs, which leads to developmental delay, hypotonia, and poor growth. For galactosemia screening two tests are widely used, metabolite assay (galactose plus galactose-1-phosphate) and measurement of GALT activity. The metabolite assay can identify all three forms of galactosemia, but ingestion of galactose/lactose is necessary to ensure detection of positive patients. The GALT test does not require galactose/lactose uptake, but it can detect only classic galactosemia. Falsepositive results can be caused by secondary inactivation of enzyme activity (by heat, etc.). Different screening strategies may be used: (1) initial measurement of total galactose, with measurement of GALT activity only in cases where early blood sampling shows elevated levels of galactose; (2) initial measurement of GALT activity and therefore restriction of screening to classic galactosaemia; and (3) measurement of both total galactose and GALT activity in all samples.

The third strategy has major advantages, yet costs only a little more. In cases of classic galactosemia, the tentative diagnosis is verified by two different methods within $2-4 \mathrm{~h}$ after sample receipt. Secondly, Duarte variants and Duarte/ classic galactosemia compound heterozygotes, which do not need treatment, are identified at a much lower rate.

\section{Cystic fibrosis}

$\mathrm{CF}$ is the most frequent metabolic disorder in the northern hemisphere. It is caused by mutations in the CF transmembrane conductance regulator gene. The gene product is a glycoprotein that regulates ion flux at epithelial surfaces. A defective CF transmembrane conductance regulator protein causes thick secretions that obstruct pancreatic ductules and lead to pancreatic insufficiency; further, the dehydration of airway surfaces leads to chronic obstructive pulmonary disease. The incidence in the Caucasian population is approximately 1:3,500. Global introduction of CF screening in the past was hampered by conflicting opinions on whether newborn screening could positively effect prognosis. However, recent studies have clearly shown the clinical, social, and economic benefit [126, 127, 178]. The initial screening parameter is IRT, measured by fluoroimmunoassay or ELISA. However, measurement of IRT has a high falsepositive rate. There are different strategies for reducing false-positive results [41]. The most promising seems to be a combination of the South Australian [179] and the UK strategy [180]. Briefly, IRT is measured in all DBS. In samples with results above the 99th percentile, DNA analysis is done. If no mutation is found and the IRT level 
is below the 99.9th percentile, there is no suspicion of CF. If the IRT level is above the 99.9th percentile (fail-safe step), or one mutation is detected, a second sample is requested. Only those newborns who either have two detectable mutations or still show elevated IRT levels in the second sample need to be referred to a specialized center for a sweat test. With this protocol the number of sweat tests required is extremely low (approximately $0.01 \%$ ), and the rate of second testing (IRT) is approximately $0.13 \%$.

The problem of false-negative IRT results, especially in meconium ileus, is not affected by this approach; therefore, the rate of false-negative screening results will be less than $0.001 \%$ (approximately one missed CF case in 150,000 screened newborns) [181, 182]. However, despite the considerable advantages of two-tier strategies, even existing programs are stepping back from DNA testing.

\section{Reasonable in selected populations}

\section{G6P-DH deficiency}

G6P-DH deficiency is the most common enzyme defect in humans. The global distribution resembles that of malaria, with the highest frequencies in tropical Africa and tropical and subtropical Asia. G6P-DH deficiency is an X-linked genetic defect that causes a variety of clinical symptoms, such as neonatal jaundice and acute hemolytic anemia, triggered by exogenous agents and oxidative stress (for a review see [120]).

\section{Hemoglobinopathies}

The incidence of hemoglobinopathies is higher in populations with African or Mediterranean decent [183]; therefore, many screening programs will only screen selected populations. However, in the future, high mobility and migration typical of modern communities will alter the situation. Recommendations in Belgium and the UK already support nonselective screening $[114,116]$.

\section{Questionable owing to major problems}

Amino acidopathies

\section{Tyrosinemia type I and homocystinuria}

Untreated tyrosinemia type I leads to liver failure during the first weeks or months of life. Homocystinuria affects the eye, skeleton, and nervous tissue, and leads to dislocation of the lens, osteoporosis, mental retardation, and thromboembolic complications that often cause stroke in the second or the third decade of life. Early treatment is desirable for both conditions [65]. Succinylacetone and homocysteine are the metabolites which primarily accumulate as a result of the enzyme defect. Unfortunately these are not easily quantifiable in routine TMS screening programs. Tyrosine and methionine, which may accumulate later, serve as secondary markers. Therefore, sensitivity is low. Because of nonspecific elevations of tyrosine levels in transient tyrosinemia, and methionine in hepatopathies or in babies on hypoallergenic alimentation, test specificity is also limited. Attempts have been made to introduce succinyl acetone and homocysteine in routine screening [68, 69, 184, 185]. However, these require either preparation of separate samples (succinyl acetone) or extra analytical procedures (homocysteine) and do not ideally meet economic screening criteria. A novel strategy for tyrosinemia screening involves extracting the same DBS twice and derivatizing the samples differently, then combining the derivatives and performing only a single measurement [66].

\section{$\beta$-Oxidation and carnitine cycle defects}

\section{Carnitine transporter defect (OCTN2)}

The carnitine transporter transfers carnitine from the extracellular matrix into the cytosol. Because renal tubular cells are unable to reabsorb carnitine, patients lose most of their ingested carnitine through the kidneys; therefore, plasma carnitine levels of most patients are extremely low. This may result in hypoglycemia, hepatic encephalopathy, cardiomyopathy, and even sudden death [107]. Newborn screening for carnitine transporter deficiency is hampered by two facts. First, the levels of free carnitine in the newborn period are strongly dependant on and influenced by maternal free carnitine levels; therefore, the free carnitine level can be normal in patients with carnitine transporter deficiency (because of high maternal levels), leading to false-negative screening results. It can also be low in normal children (because of low maternal levels), leading to false positives. Second, decreased levels of free carnitine can lead to diagnosis of a carnitine transporter deficiency in the (asymptomatic) mother. Despite being asymptomatic in adulthood, some of the mothers, detected through newborn screening of their child, had one or more episodes of metabolic decompensation in early childhood, requiring hospitalization; no definite diagnosis was made at that time. While it is reasonable to detect affected newborns, since metabolic decompensation may be prevented by simple carnitine substitution, it is problematic to detect asymptomatic mothers, because nothing is known about the risk of metabolic decompensation in adulthood. This leads to the ethical problem of whether or not to treat an adult who is, so far, clinically healthy. 
Organic acidurias

Propionic acidemia, methylmalonic acidemia, and disorders of cobalamin metabolism

Propionic acidemia, methylmalonic acidemia, and disorders of cobalamin metabolism (except types E and $G$ ) all have the same marker metabolite, propionylcarnitine. For the severe forms, clinical symptoms (vomiting, failure to thrive), biochemical findings (ketoacidosis, hyperammonemia), and the initial therapeutic approach are also quite similar (for reviews see $[186,187])$. The different disorders cannot be discriminated through DBS acylcarnitine profiles. However, inclusion of a DBS homocysteine determination could improve both specificity and sensitivity for disorders of cobalamin metabolism. So far, there is no evidence that patients detected by newborn screening have a more favorable outcome than patients detected clinically [90].

\section{3-Methylcrotonyl-CoA carboxylase deficiency}

3-Methylcrotonyl-CoA carboxylase (3-MCC) deficiency was formerly thought to be a very rare organic aciduria. Patients usually present with vomiting, opisthotonos, seizures, and coma. With the introduction of TMS-based newborn screening, it turned out that elevations of the marker metabolite (hydroxyisovaleryl carnitine) was the most common anomaly seen in the acylcarnitine profile [188]. However, very few children with abnormal biochemistry develop symptoms typical of 3-MCC deficiency. In addition, a great number of biochemically affected, but clinically normal mothers were detected owing to elevated hydroxyisovaleryl carnitine levels in newborn screening samples of their children [189]. The results of the Munich study [95] and a second study from Switzerland [190] strongly suggest that newborn screening for 3-MCC deficiency causes more harm (stigmatization, anxiety, decreased quality of life) than good; therefore, newborn screening for 3-MCC deficiency was discontinued in Germany.

Nevertheless, a consensus clinical practice protocol for the diagnosis and management of 3-MCC deficiency has been published [191].

\section{3-Hydroxymethylglutaryl-CoA lyase deficiency, 3-methylcrotonylglycinuria, holocarboxylase synthase deficiency, and $\beta$-ketothiolase deficiency}

These disorders have the same primary marker metabolite as 3-MCC deficiency, 3-hydroxyisovaleryl carnitine; however, the concentrations are 10-20-fold lower than in severe 3-MCC deficiency. Although they are very rare, all of these diseases could benefit from early treatment. However, inclusion of these disorders in a screening program is only possible at the cost of a high recall rate and the fact that the nondisease 3-MCC deficiency is codetected.

Urea cycle disorders

Newborns with neonatal onset of urea cycle disorders, e.g., severe forms of citrullinemia, usually become symptomatic during the first days of life. In most cases diagnosis precedes the screening result; therefore, screening appears to be unnecessary.

Beyond that, screening for urea cycle disorders is problematic for several other reasons. Some of the disorders, such as deficiencies of $N$-acetylglutamate synthase, carbamoylphosphate synthase, and ornithine transcarbamylase, are not detected by TMS screening in early life because of normal amino acid profiles. Furthermore, quantitation of the basic amino acids citrulline, argininosuccinic acid, and arginine is analytically more problematic than that of other amino acids that may cause false positives. Finally, screening for citrullinemia yields a high proportion of children with mild enzyme defects, but without clinical symptoms [192].

Arginase deficiency seems to be the only urea cycle disorder suitable for newborn screening, because the onset of clinical symptoms is later than in other urea cycle defects and early treatment improves prognosis [73, 74].

\section{Value of newborn screening not yet settled}

Malonyl-CoA decarboxylase deficiency and disorders of creatine metabolism

The feasibility of newborn screening for these disorders has been demonstrated [94, 123, 193]. Patients clearly benefit from treatment, which prevents cardiac decompensation in malonyl-CoA decarboxylase deficiency and can prevent severe developmental delay. Creatine supplementation in patients with disorders of creatine metabolism improves extrapyramidal movement disorders [194]. However, so far no results from prospective studies or pilot projects are available.

\section{Discontinued}

\section{Histidinemia}

Histidinemia is a common disorder of amino acid metabolism with an incidence similar to that of PKU. The underlying defect is a deficiency in histidase [77]. Because some patients with developmental deficits exhibited high histidine levels [78-80], a causal relationship was suspected. However, a prospective study conducted over a 28-year period in Manchester with 104 patients clearly 
showed that histidinemia is a benign metabolic condition that does not require treatment [81].

\section{Hydroxyprolinemia}

Hydroxy-l-proline oxidase deficiency is a rare autosomal recessive disorder of hydroxyproline catabolism. Formerly hydroxyproline was detected by screening programs that used thin-layer chromatography for PKU screening. With the introduction of TMS to newborn screening, hydroxproline is detected together with the isobaric amino acids leucine, isoleucine, and alloisoleucine.

Despite the fact that, for decades, hydroxyprolinemia has been regarded as a harmless biochemical abnormality [82, 83], recently two new "patients" have been reported; these were detected by TMS newborn screening [84, 195]. Clearly, such elevated hydroxyproline levels should not be reported.

\section{Neuroblastoma}

Neuroblastoma, a malignant tumor of embryonal cells in the neural crest, is a rare childhood cancer. From 1:7,000 to 1:10,000 liveborn children develop clinically relevant neuroblastoma before the age of 15 . The incidence in the first year of life is about 30 per million and drops to less than one per million at the age of 15 years. The tumors secrete catecholamine and dopamine; abnormal levels of their metabolites, vanillylmandelic acid and especially homovanillic acid, are excreted in the urine. The tumors are categorized into six stages (I, IIA, IIB, III, IV, and IVS), with increasing severity and decreasing survival rate at diagnosis for stages I-IV. The survival rate for stage I is nearly $100 \%$, but is less than $20 \%$ for stage IV. Screening programs for neuroblastoma used filter paper soaked with urine taken at the age of 6 months. This type of sample collection made posting to centralized laboratories quite easy. However, studies in North America and Germany showed that there is no clear evidence for a positive effect of screening, i.e., a reduction of death rate due to neuroblastoma. Rather, screening showed a negative effect in the sense that tumors (especially of stages I and IVS) were obviously overdiagnosed, because quite a few of those tumors showed spontaneous regression without therapy (for a review see [141]). Despite these negative results [142], a new screening approach has recently been proposed in Japan [196].

\section{Further problems and concerns}

\section{DNA Testing}

Although genetic testing can also be accomplished on the metabolite or protein level (Fig. 1), the term "genetic testing" in the strictest sense applies only to techniques which analyze DNA and RNA. Genetic tests are used as a healthcare tool to detect gene variants associated with a specific disease or condition; they are also used in nonclinical applications such as paternity testing and forensics. They can confirm a suspected diagnosis and also predict the possibility of future illness. The recent development of chip technologies and multiparameter tests makes it likely that genetic tests will increasingly be used in diagnostic applications. Mutations causing illness will be detected with simple and cost-effective tests. Economic arguments therefore will not stop the introduction of these technologies.

DNA tests can also supplement newborn screening. They can be especially helpful as second-tier tests that confirm or exclude a disease when the primary test for a protein or metabolite level is positive; CF testing is the classic example.

Of course, they can also be used for primary screening; however, screening agencies will have to address several issues if they are using DNA testing as a primary screen:

- Carrier detection. As well as detecting children that may be at risk, DNA tests simultaneously reveal that unaffected individuals (the parents) are carriers. Knowledge that they are carriers may be important to these parents for future family planning. Therefore, genetic counseling is mandatory when DNA tests are used. If an entire population is screened, it may be difficult to keep this claim of adequate information alive.

- Fear of genetic testing. Since people have become concerned about the possible misuse of genetic information, especially in health insurance and employment, these public fears of genetic discrimination may hinder scientific advances in newborn screening [197]. To be successful, a population screening requires a high participation rate, i.e., all newborns must be examined. Since informed consent is mandatory, successful newborn screening requires the parents' acceptance [198]. Unfortunately, the general public is frequently unable to discriminate between the directed search for or exclusion of a specific disease and an undirected multiparameter exploration of the whole genome. Therefore, the inclusion of DNA tests in newborn screening may lower participation. When new technologies are being introduced, every effort must be made to keep public information and the resulting participation rate high.

\section{The burden of nondisease}

"Non-disease" is a medical problem that some have defined as a medical problem but where people may have better outcomes if the problem was not defined in that way' 
[199]. With respect to newborn screening, nondisease may be defined as a biochemical condition, differing from normal, which may never cause a disease (in the narrow sense that disease equals developing symptoms). However, when confronted with such a diagnosis, the child, its family, and the public health system must currently shoulder a considerable burden.

Most target diseases of newborn screening are caused by enzyme deficiencies that result in biochemical abnormalities. If the deficiency is only partial, residual enzyme activity may be sufficient for maintaining proper physiologic function. Thus, the child will test positive, but will never suffer from the corresponding disease.

Although the spectrum of diseases that can be detected analytically has increased during the last decade, especially after the introduction of TMS, the detection of nondisease is not a new issue. For instance, during a screen for PKU, the nondisease hyperphenylalaninemia, which does not require treatment, is also detected because the marker metabolites are the same for both. However, in this case there is agreement on the approaches used for confirmation and treatment. Cut-off levels and decision thresholds for the start of treatment are well defined and internationally consistent.

Problems associated with nondisease have even arisen in screens for MCAD deficiency. The positive effect of screening is unquestioned, and a considerable reduction in mortality and morbidity is well documented [200]. However, patients detected by newborn screening show a different mutational pattern from those detected clinically. The common mutation c. $935 \mathrm{~A}>\mathrm{G}$ (Lys329Glu) is less common in the newborn screening population than in the population detected via clinical symptoms. Moreover, a mild folding variant c.199T $>\mathrm{C}$ (Tyr67His), so far not reported in clinically symptomatic patients, is quite frequent in patients detected by newborn screening $[102,201]$. The spectrum of clinical severity in MCAD-deficient patients seems to range from severe neonatal onset to mild variants that may never become symptomatic. Unfortunately there seems to be no good way to predict risk.

For those diseases which have a poorly defined history, additional problems remain. Two typical examples are 3MCC deficiency and carnitine transporter deficiency.

3-MCC deficiency was part of the Bavarian pilot project to evaluate expansion of newborn screening. This pilot project [95] produced a result for 3-MCC deficiency that was consistent with the result from a Swiss study [190]. These two studies investigated a total of 47 patients whose (biochemical) 3-MCC deficiency was detected by newborn screening, and an additional four siblings and nine mothers who were detected through family investigations. On the basis of the results of the newborn screening in Bavaria and published cases of clinically diagnosed 3-MCC deficiency, a cautious calculation was made to estimate the risk that patients with biochemical 3-MCC deficiency would develop symptoms. The risk of death was estimated to be approximately $1: 8,500,000$, and the risk of developing clinical symptoms was estimated to be approximately $1: 1,200,000$. This means that far less than $10 \%$ of biochemically affected individuals might develop minor clinical symptoms, and less than $1-2 \%$ might have a risk of severe outcome. In addition, both groups did not show a clear correlation between genotype and phenotype, suggesting that other factors in addition to the genotype at the 3-MCC loci might have a major influence on the phenotype of 3-MCC deficiency.

For carnitine transporter deficiency the situation was quite similar [97, 107, 202]; however, the clinical expressivity and penetrance, or susceptibility to metabolic decompensation (at least in childhood) might be higher than in 3-MCC deficiency.

Those who make decisions about newborn screening panels need to carefully balance the positive and negative effects of screening for a certain condition. At the screening stage, the choice to include or exclude a condition still exists. Once a patient has been identified, it can be quite problematic to decide not to treat that individual (who is healthy so far) in the absence of scientific evidence that a certain condition does not cause disease. Gaining such evidence might take decades and lead to dozens of unnecessarily treated individuals, as we have learned from our experience with histidinemia [203].

\section{Maintaining process quality in newborn screening}

Newborn screening is a complex process, with many people and institutions involved. Midwives, nurses, obstetricians, and pediatricians at the maternity clinic are the first link of the chain. The mail delivery service, the screening laboratory, local pediatricians, and metabolism or endocrinology centers are the other links. In this context, screening failure cannot be solely defined as a laboratory error. Rather, screening failure means a child with a disease that is included in the screening program is not treated for this disorder until it develops clinical symptoms. The reasons for failure can be manifold and can occur at all stages of newborn screening: For example, failure could be due to forgotten specimen collection, mix-up of newborns, samples lost during delivery, laboratory errors, errors in communicating a positive screening result, follow-up specimen not received, etc.

"Fail-safe" mechanisms were defined more than 20 years ago [204]. Quality control schemes that check the performance of the screening laboratories are available worldwide. However, mechanisms to check the integrity of the whole process are rather rare. 
Nonetheless, it is still possible to check the integrity of the screening process, as will be shown by two examples. In the Netherlands newborn screening is operated under the supervision of Dutch National Institute for Health and the Environment (RIVM). Every newborn must be registered at the local town hall immediately after birth. After registration the regional vaccination authority is informed and every child is given a specific screening number. After $72 \mathrm{~h}$ blood for newborn screening is drawn by a health-center assistant or an obstetrics assistant. Tracking of positive screening results is also supervised by the RIVM. In Bavaria (Germany) the public health screening center is in charge of ensuring that every newborn is screened. After informed consent has been obtained, the screening center will receive notification from the screening laboratory that a certain child has been screened. The screening center now distributes the notifications to the corresponding local health authorities, where the newborns must be registered. The local health authorities check that every child in their field of responsibility is screened. The public health screening center is also responsible for tracking of positive screening results $[199,205]$.

Other screening programs may have different ways to check the integrity of the screening process. Other reasons for false-negative screening results, such as exchange transfusion, dopamine or corticosteroid therapy, and highdose glucose infusion during the first days of life, are well known. Therefore, continuous education of the many (frequently changing) people involved in blood collection is crucial so that the procedures for drawing a second screening sample at the right time are well established.

\section{Challenge of further extension}

Every effort should be made to keep the success and positive reputation of newborn screening high. This requires continuously working on and, if possible, improving the sensitivity and specificity of newborn screening. Newborn screening programs should base further extension on established scientific knowledge. However, inclusion criteria for target diseases must also be strictly taken into account. Decision-makers must consider the benefit to the individual patients and their families, to the community, and to the health-care system.

\section{References}

1. Wald NJ (1994) J Med Screen 1:76

2. Wilson JMG, Jungner G (1968) Public health papers no 34. World Health Organization, Geneva

3. Wald NJ (2001) J Med Screen 8:169

4. Bickel H (1954) Exp Med Surg 12:114-117

5. Bickel H, Gerrard J, Hickmans EM (1954) Acta Pediatr 43:6477
6. Armstrong MD, Low NL, Bosma JF (1957) Am J Clin Nutr 5:543-554

7. Fölling A (1934) Z Physiol Chem 227:169-176

8. Armstrong MD, Tyler FH (1955) J Clin Invest 34:565-580

9. Guthrie R, Susi A (1963) Pediatrics 32:338-343

10. Jervis GA (1937) Arch Neurol Psychiatry 38:944-963

11. Jervis GA (1939) J Ment Sci 85:719-762

12. Naylor EW, Guthrie R (1978) Pediatrics 61:262-266

13. Yap S, Naughten E (1998) J Inherit Metab Dis 21:738-747

14. Levy HL, Shih VE, Madigan PM (1974) N Engl J Med 5:12141219

15. Beutler E, Baluda MC (1966) J Lab Clin Med 68:137-141

16. Paigen K, Pacholec F, Levy HL (1982) J Lab Clin Med 99:895-907

17. Larsen PR, Broskin K (1975) Pediatr Res 9:604-609

18. Dussault JH, Parlow A, Letarte J, Guyda H, Laberge C (1976) J Pediatr 89:550-552

19. Heard GS, Secor McVoy JR, Wolf B (1984) Clin Chem 30:125-127

20. Piazzi S, Capelli M, Paolini M, Perugini D, Grossi G, Balsamo A, Salomoni P, Cassio A, Bugiardini G, Cacciari E (1982) J Endocrinol Invest 5:87-90

21. Yaswon GI, Huntsman RG, Metters JS (1970) J Clin Pathol 23:533-537

22. Beutler E (1966) Blood 28:553-562

23. Ryley HC, Robinson PG, Yamashiro Y, Bradley DM (1981) J Clin Pathol 34:906-910

24. Millington DS, Kodo N, Norwood DL, Roe CR (1990) J Inherit Metab Dis 13:321-324

25. Chace DH, Kalas TA, Naylor EW (2003) Clin Chem 49:17971817

26. Wilcken B, Wiley V, Hammond J, Carpenter K (2003) N Engl J Med 348:2304-2312

27. Chace DH, Kalas TA (2005) Clin Biochem 38:296-309

28. Röschinger W, Olgemöller B, Fingerhut R, Liebl B, Roscher AA (2003) Eur J Pediatr 162:S67-S76

29. Sawada T, Kidowaki T, Sakamoto I, Hashida T, Matsumura T, Nakagawa M, Kusunoki T (1984) Cancer 53:2731-2735

30. Wald NJ (1996) J Med Screen 3:57

31. Harper PS (1996) J Med Screen 3:165-166

32. Paigen K, Pacholec F, Levy HL (1982) J Lab Clin Med 99:895907

33. Berry GT, Nissim I, Gibson JB, Mazur AT, Lin Z, Elsas LJ, Singh RH, Klein PD, Segal S (1997) Eur J Pediatr 156:S43-S49

34. Diepenbrock F, Heckler R, Schickling H, Engelhard T, Bock D, Sander J (1992) Clin Biochem 25:37-39

35. Rhode H, Elei E, Taube I, Podskarbi T, Horn A (1998) Clin Chim Acta 274:71-87

36. Lin HC, Kirby LT, Ng WG (1994) Hum Genet 93:167-169

37. Elsas LJ, Dembure PP, Langley S, Paulk EM, Hjelm LN, Fridovich-Keil J (1994) Am J Hum Genet 54:1030-1036

38. Dobrowolski SF, Banas RA, Suzow JG, Berkley M, Naylor EW (2003) J Mol Diagn 5:42-47

39. Seltzer WK, Accurso F, Fall MZ, VanRiper AJ, Descartes M, Huang Y, McCabe ER (1991) Biochem Med Metab Biol 1:105109

40. Kösel S, Burggraf S, Fingerhut R, Dörr HG, Roscher AA, Olgemöller B (2005) Clin Chem 51:298-304

41. Wilcken B (2007) J Inherit Metab Dis 30:537-543

42. Wilcken B, Towns SJ, Mellis CM (1983) Arch Dis Child 58:863-866

43. Sarles J, Barthellemy S, Férec C, Iovanna J, Roussey M, Farriaux JP, Toutain A, Berthelot J, Maurin N, Codet JP, Berthézène P, Dagorn JC (1999) Arch Dis Child Fetal Neonatal Ed 80:118-122

44. Sarles J, Berthézène P, Le Louarn C, Somma C, Perini JM, Catheline M, Mirallié S, Luzet K, Roussey M, Farriaux JP, Berthelot J, Dagorn JC (2005) J Pediatr 147:302-305 
45. Barthellemy S, Maurin N, Roussey M, Férec C, Murolo S, Berthézène P, Iovanna JL, Dagorn JC, Sarles J (2001) Arch Pediatr 8:275-281

46. Taimela E, Aalto M, Viikari J, Nuutila P, Irjala K (1995) Scand J Clin Lab Invest 55:537-541

47. Thomson JJ (1909) Philos Mag VI 18:821-845

48. Yost RA, Enke CGJ (1978) Am Chem Soc 100:2274

49. Dole M, Mack LL, Hines RL, Mobley RC, Ferguson LD, Alice MB (1968) J Chem Phys 49:2240

50. Yamashita M, Fenn JB (1984) J Phys Chem 88:4451

51. Yamashita M, Fenn JB (1984) J Phys Chem 88:4671

52. Gempel K, Olgemöller B (2008) Anal Bioanal Chem (in preparation)

53. Therrell BL, Berenbaum SA, Manter-Kapanke V, Simmank J, Korman K, Prentice L, Gonzalez J, Gunn S (1998) Pediatrics 101:583-590

54. Simon E, Schwarz M, Roos J, Dragano N, Geraedes M, Siegridt J, Kamp G, Wendel U (2008) Health Qual Life Outcomes 6:25 doi:10.1186/1477-7525-6-25

55. Michalis-Matalon K (2008) Expert Opin Investig Drugs 17:245251

56. Giovanni M, Verduci E, Salvatici E, Fiori L, Riva E (2007) J Inherit Metab Dis 30:145-152

57. Matalon R, Michals-Matalon K, Bhatia G, Burlina AB, Burlina AP, Braga C, Fiori L, Giovannini M, Grechanina E, Novikov P, Grady J, Tyring SK, Guttler F (2007) J Inherit Metab Dis $30: 153-158$

58. Muntau AC, Röschinger W, Habich M, Demmelmair H, Hoffmann B, Sommerhoff CP, Roscher AA (2002) N Engl J Med 347:2122-2132

59. Chuang D, Shih V (2001) In: Scriver CR, Beaudet AL, Sly WS, Valle D (eds) The metabolic and molecular bases of inherited disease. 8th edn. McGraw-Hill, New York, pp 1971-2009

60. Morton DH, Strauss KA, Robinson DL, Puffenberger EG, Kelley RI (2002) Pediatrics 109:999-1008

61. Heldt K, Schwahn B, Marquardt I, Grotzke M, Wendel U (2005) Mol Genet Metab 84:313-316

62. Simon E, Fingerhut R, Baumkotter J, Konstantopoulou V, Ratschmann R, Wendel U (2006) J Inherit Metab Dis 29:532537

63. Peterschmitt MJ, Simmons JR, Levy HL (1999) N Engl J Med 341:1572-1576

64. Linnebank M, Homberger A, Junker R, Nowak-Goettl U, Harms E, Koch HG (2001) Thromb Haemost 85:986-988

65. Pass KA, Morrissey M (2008) Clin Chem 54:627-629

66. Turgeon C, Magera MJ, Allard P, Tortorelli S, Gavrilov D, Oglesbee D, Raymond K, Rinaldo P, Matern D (2008) Clin Chem 54:657-664

67. La Marca G, Malvagia S, Pasquini E, Innocenti M, Fernandez MR, Donati MA, Zammarchi E (2008) Rapid Commun Mass Spectrom 22:812-816

68. Johnson DW, Gerace R, Ranieri E, Trinh MU, Fingerhut R (2007) Rapid Commun Mass Spectrom 21:59-63

69. Sander J, Janzen N, Peter M, Sander S, Steuerwald U, Holtkamp U, Schwahn B, Mayatepek E, Trefz FK, Das AM (2006) Clin Chem 52:482-487

70. Enns GM, Berry SA, Berry GT, Rhead WJ, Brusilow SW, Hamosh A (2007) N Engl J Med 356:2282-2292

71. Francois B, Cornu G, de Meyer R (1976) Arch Dis Child $51: 228-231$

72. Crombez EA, Cederbaum SD (2005) Mol Genet Metab 84:243251

73. Cederbaum SD, Yu H, Grody WW, Kern RM, Yoo P, Iyer RK (2002) Mol Genet Metab 81:S38-S44

74. Scaglia F, Lee B (2006) Am J Med Genet C Semin Med Genet 142:113-120
75. Cleary MA, Dorland L, de Koning TJ, Poll-The BT, Duran M, Mandell R, Shih VE, Berger R, Olpin SE, Besley GT (2005) J Inherit Metab Dis 28:673-679

76. Boneh A, Allan S, Mendelson D, Spriggs M, Gillam LH, Korman SH (2008) Mol Genet Metab 94:143-147

77. Ito F, Aoki K, Eto Y (1981) J Biochem 135:227-229

78. Garvey AM, Gordon N (1969) Br J Disord Commun 4:146-150

79. Ishikawa M (1987) Acta Paediatr Jpn 29:224-228

80. Duffner PK, Cohen ME (1975) Neurology 25:195-197

81. Lam WK, Cleary MA, Wraith JE, Walter JH (1996) Arch Dis Child 74:343-346

82. Pelkonen R, Kivirikko KI (1970) N Engl J Med 283:451-456

83. Prockop DJ (1970) N Engl J Med 283:487

84. Baykal T, Karaaslan I, Gokcay G, Demir F, Laleli Y, Demirkol M (2004) J Inherit Metab Dis 27:781-782

85. Lindner M, Ho S, Fang-Hoffmann J, Hoffmann GF, Kölker S (2006) J Inherit Metab Dis 29:378-382

86. Fingerhut R, Brackmann R, Röschinger W, Hiedl S, Roscher AA, Olgemöller B (2003) Clin Chem Lab Med 41:S97

87. Tanaka K (1990) Prog Clin Biol Res 321:273-290

88. Ensenauer R, Vockley J, Willard JM, Huey JC, Sass JO, Edland SD, Burton BK, Berry SA, Santer R, Grünert S, Koch HG, Marquardt I, Rinaldo P, Hahn S, Matern D (2004) Am J Hum Genet 75:1136-1142

89. Sass JO, Hofmann M, Skladal D, Mayatepek E, Schwahn B, Sperl W (2004) Clin Pediatr Phila 43:837-843

90. Dionisi-Vici C, Deodato F, Röschinger W, Rhead W, Wilcken B (2006) J Inherit Metab Dis 29:383-389

91. Allen RH, Stabler SP, Savage DG, Lindenbaum J (1993) FASEB J 7:1344-1353

92. Zavadakova P, Fowler B, Zeman J, Suormala T, Pristoupilová K, Kozich V, Zavad'áková P (2002) J Inherit Metab Dis 6:461-476

93. Salomons GS, Jakobs C, Pope LL, Errami A, Potter M, Nowaczyk M, Olpin S, Manning N, Raiman JA, Slade T, Champion MP, Peck D, Gavrilov D, Hillman R, Hoganson GE, Donaldson K, Shield JP, Ketteridge D, Wasserstein M, Gibson KM (2007) J Inherit Metab Dis 30:23-28

94. Santer R, Fingerhut R, Lässker U, Wightman PJ, Fitzpatrick DR, Olgemöller B, Roscher AA (2003) Clin Chem 49:660-662

95. Stadler SC, Polanetz R, Maier EM, Heidenreich SC, Niederer B, Mayerhofer PU, Lagler F, Koch HG, Santer R, Fletcher JM, Ranieri E, Das AM, Spiekerkötter U, Schwab KO, Pötzsch S, Marquardt I, Hennermann JB, Knerr I, Mercimek-Mahmutoglu S, Kohlschmidt N, Liebl B, Fingerhut R, Olgemöller B, Muntau AC, Roscher AA, Röschinger W (2006) Hum Mutat 27:748-759

96. Gibson KM, Breuer J, Nyhan WL (1988) Eur J Pediatr 148:180 186

97. Lund AM, Joensen F, Hougaard DM, Jensen LK, Christensen E, Christensen M, Nørgaard-Petersen B, Schwartz M, Skovby F (2007) J Inherit Metab Dis 30:341-349

98. Fukao T, Zhang GX, Sakura N, Kubo T, Yamaga H, Hazama A, Kohno Y, Matsuo N, Kondo M, Yamaguchi S, Shigematsu Y, Kondo N (2003) J Inherit Metab Dis 26:423-431

99. Ristoff E, Larsson A (2007) Orphanet J Rare Dis 2:16 doi:10.1186/1750-1172-2-16

100. van Maldegem BT, Duran M, Wanders RJ, Niezen-Koning KE, Hogeveen M, Ijlst L, Waterham HR, Wijburg FA (2006) JAMA 296:943-952

101. Rhead WJ (2006) J Inherit Metab Dis 29:370-377

102. Maier EM, Liebl B, Röschinger W, Nennstiel-Ratzel U, Fingerhut R, Olgemöller B, Busch U, Krone N, v Kries R, Roscher AA (2005) Hum Mutat 25:443-452

103. Liebig M, Schymik I, Mueller M, Wendel U, Mayatepek E, Ruiter J, Strauss AW, Wanders RJ, Spiekerkoetter U (2006) Pediatrics 118:1065-1069 
104. den Boer ME, Wanders RJ, Morris AA, IJlst L, Heymans HS, Wijburg FA (2002) Pediatrics 109:99-104

105. Schaefer J, Jackson S, Dick DJ, Turnbull DM (1996) 40:597-602

106. Das AM, Fingerhut R, Wanders RJ, Ullrich K (2000) Eur J Pediatr 159:243-246

107. Schimmenti LA, Crombez EA, Schwahn BC, Heese BA, Wood TC, Schroer RJ, Bentler K, Cederbaum S, Sarafoglou K, McCann M, Rinaldo P, Matern D, di San Filippo CA, Pasquali M, Berry SA, Longo N (2007) Mol Genet Metab 90:441-445

108. Fingerhut R, Röschinger W, Muntau AC, Dame T, Kreischer J, Arnecke R, Superti-Furga A, Troxler H, Liebl B, Olgemöller B, Roscher AA (2001) Clin Chem 47:1763-1768

109. Albers S, Marsden D, Quackenbush E, Stark AR, Levy HL, Irons M (2001) Pediatrics 107:E103

110. Pierre G, Macdonald A, Gray G, Hendriksz C, Preece MA, Chakrapani A (2007) J Inherit Metab Dis 30:815

111. Wang ST, Pizzolato S, Demshar HP (1998) Clin Chim Acta 274:151-158

112. Forest MG (2004) Hum Reprod Update 10:469-485

113. Schreiner F, Brack C, Salzgeber K, Vorhoff W, Woelfle J, Gohlke B (2007) doi:10.1007/s00431-007-0505-0

114. Gulbis B, Ferster A, Cotton F, Lebouchard M-P, Cochaux P, Vertongen F (2006) J Med Screen 13:76-78

115. Gulbis B, Fontaine B, Verlangen F, Cotton F (2003) Ann Clin Biochem 40:659-662

116. Wild BJ, Green BN, Stephens AD (2004) Blood Cells Mol Dis 33:308-317

117. Wolf B, Grier RE, Allen RJ, Goodman SI, Kien CL (1983) Clin Chim Acta 131:273-281

118. Ramaekers VT, Suormala TM, Brab M, Duran R, Heimann G, Baumgartner ER (1992) Arch Dis Child 67:115-119

119. Segal S, Berry GT (1995) In: Sriver CR, Beaudet AL, Sly WS, Valle D (eds) The metabolic and molecular bases of inherited disease. 7th edn. McGraw-Hill, New York, pp 967-1000

120. Cappellini MD, Fiorelli G (2008) Lancet 371:64-74

121. Bodamer OA, Bloesch SM, Gregg AR, Stöckler-Ipsiroglu S, O'Brien WE (2001) Clin Chim Acta 308:173-178

122. Stromberger C, Bodamer OA, Stöckler-Ipsiroglu S (2003) J Inherit Metab Dis 2-3:299-308

123. Carducci C, Santagata S, Leuzzi V, Carducci C, Artiola C, Giovanniello T, Battini R, Antonozzi I (2006) Clin Chim Acta 364:180-187

124. Meikle PJ, Ranieri E, Simonsen H, Rozaklis T, Ramsay SL, Whitfield PD, Fuller M, Christensen E, Skovby F, Hopwood JJ (2004) Pediatrics 114:909-916

125. Li Y, Scott CR, Chamoles NA, Ghavami A, Pinto BM, Turecek F, Gelb MH (2004) Clin Chem 50:1723-1724

126. Wilcken B, Gaskin K (2007) Lancet 369:1146-1147

127. Sims EJ, Mugford M, Clark A, Aitken D, McCormick J, Mehta G, Mehta A (2007) Lancet 369:1187-1195

128. McKay KO (2007) J Inherit Metab Dis 30:544-555

129. Roussey M, Le Bihannic A, Scotet V, Audrezet MP, Blayau M, Dagorne M, David V, Deneuville E, Giniès JL, Laurans M, Moisan-Petit V, Rault G, Vigneron P, F'rec C (2007) J Inherit Metab Dis 30:613 doi:10.1007/s10545-007-0633-8

130. Lorini R, Minicucci L, Napoli F, Padovani P, Bazzigaluppi E, Tortoioli C, Cherubini V, Bottazzo G, Pozzilli P, Falorni A, Buzzetti R (2005) Acta Biomed 76(Suppl.3):31-35

131. Zhang VW, McPherson B, Shi BX, Tang JL, Wong BY (2008) Int J Pediatr Otorhinolaryngol 72:351-360

132. Barbi M, Binda S, Caroppo S, Primache V (2006) J Clin Virol 35:206-209

133. Barbi M, Binda S, Caroppo S (2006) Rev Med Virol 16:385-392

134. Barbi M, MacKay WG, Binda S, van Loon AM (2008) BMC Microbiol 8:2 doi:10.1186/1471-2180-8-2

135. Nance WE, Lim BG, Dodson KM (2006) J Clin Virol 35:221-225
136. Ross SA, Fowler KB, Ashrith G, Stagno S, Britt WJ, Pass RF, Bopanna SB (2006) J Pediatr 148:332-336

137. Peckham C, Tookey P, Logan S, Giaquinto C (2001) J Med Screen 8:119-124

138. Walter S, Atkinson C, Sharland M, Rice P, Raglan E, Emery VC, Griffiths PD (2008) Arch Dis Child Fetal Neonatal Ed 93:F280 285

139. Gilbert RE, Peckham CS (2002) J Med Screen 9:135-141

140. Stevens R, Pass K, Fuller S, Wiznia A, Noble L, Duva S, Neal M (1992) J Clin Microbiol 30:2353-2358

141. Chamberlain J (1994) J Med Screen 1:169-175

142. Maris JM, Woods WG (2008) Lancet 371:1142-1143

143. Hiyama E, Iehara T, Sugimoto T, Fukuzawa M, Hayashi Y, Sasaki F, Sugiyama M, Kondo S, Yoneda A, Yamaoka H, Tjiri T, Akazawa K, Ohtaki M (2008) Lancet 371:1173-1180

144. Bradley DM, Parsons EP, Clarke AJ (1993) BMJ 306:357-360

145. Parsons EP, Clarke AJ, Hood K, Lycett E, Bradley DM (2002) Arch Dis Child Fetal Neonatal Ed 86:F91-F95

146. Huang H, Manton KG (2005) Front Biosci 10:1024-1039

147. de Castro Toledo AC Jr, Januário JN, Rezende RMS, Siqueira AL, de Mello BF, Fialho ÉL, Ribeiro RA, da Silva HL, Pires ÉC, Simões TC, Greca DB (2005) Mem Inst Oswaldo Cruz 100:365-370

148. de Castro Toledo AC Jr, Januário JN, Rezende RMS, Siqueira AL, de Mello BF, Fialho ÉL, Ribeiro RA, da Silva HL, Pires ÉC, Simões TC, Greca DB (2005) Mem Inst Oswaldo Cruz 100:365-370

149. Mendy M, Kirk GD, van der Sande M, Jeng-Barry A, Lesi OA, Hainaut P, Sam O, McConkey S, Whittle H (2005) J Viral Hepat 12:642-647

150. Illig R, Largo RH, Quin Q, Torresani T, Rochiocciolo P, Klett M (1988) Dtsch Med Wochenschr 104:667-671

151. New MI (1998) Annu Rev Med 49:311-328

152. Speiser W, Dupont J, Zhu D, Serrat J, Buegeleisen M, TusieLuna MT (1992) J Clin Invest 90:584-595

153. Torresani T, Grüters A, Scherz R, Burckhardt JJ, Harras A, Zachmann M (1994) Screening 3:77-84

154. Allan DB, Hoffman GL, Fitzpatrick P, Laessig R, Maby S, Slyper A (1997) J Pediatr 130:128-133

155. Olgemöller B, Roscher AA, Liebl B, Fingerhut R (2003) J Clin Endocrinol Metab 88:5790-5794

156. Lacey JM, Minutti CZ, Magera MJ, Tauscher AL, Casetta B, McCann M, Lymp J, Hahn SH, Rinaldo P, Matern D (2004) Clin Chem 50:621-625

157. Janzen N, Peter M, Sander S, Steuerwald U, Terhardt M, Holtkamp U, Sander J (2007) J Clin Endocrinol Metab 92:2581-2589

158. Ye J, Liu X, Ma X, Zhang Y, Huang X, Chen R, Gu X (2002) Chin Med J Engl 115:217-221

159. Puffenberger EG (2003) Am J Med Genet C Semin Genet 121C:18-31

160. NN (1973) Acta Paediat Scand 62:413-416

161. Chace DH, Sherwin JE, Hillman SL, Lorey F, Cunningham GC (1998) Clin Chem 44:2405-2409

162. DiGeorge AM, Rezvani I, Garibaldi LR, Schwartz M (1982) N Engl J Med 307:1492-1495

163. Wendel U, Lombeck I, Bremer HJ (1983) N Engl J Med 308:1100-1101

164. Shih VE (1984) N Engl J Med 310:596-597

165. Kyllerman M, Steen G (1980) Arch Fr Pediatr 37:279-279

166. Smith WE, Millington DS, Koeberl DD, Lesser PS (2001) Pediatrics 107:1184-1187

167. Kölker S, Christensen E, Leonard JV, Greenberg CR, Burlina AB, Burlina AP, Dixon M, Duran M, Goodman SI, Koeller DM, Müller E, Naughten ER, Neumaier-Probst E, Okun JG, Kyllerman M, Surtees RA, Wilcken B, Hoffmann GF, Burgard P (2007) J Inherit Metab Dis 30:5-22

168. Gallagher RC, Cowan TM, Goodman SI, Enns GM (2005) Mol Genet Metab 86:417-420 
169. Christensen E, Ribes A, Busquets C, Pineda M, Duran M, PollThe BT, Greenberg CR, Leffers H, Schwartz M (1997) J Inherit Metab Dis 20:383-386

170. Vockley J, Ensenauer R (2006) Am J Med Genet C Semin Med Genet 142:95-103

171. van Calcar SC, Gleason LA, Lindh H, Hoffman G, Rhead W, Vockley G, Wolff JA, Durkin MS (2007) WMJ 106:12-15

172. Sass JO, Ensenauer R, Röschinger W, Reich H, Steuerwald U, Schirrmacher O, Engel K, Häberle J, Andresen BS, Mégarbané A, Lehnert W, Zschocke J (2008) Mol Genet Metab 93:30-35

173. Wilson CJ, Champion MP, Collins JE, Clayton PT, Leonard JV (1999) Arch Dis Child 80:459-462

174. Zschoke J, Schulze A, Lindner M, Fiesel S, Olgemöller K, Hoffmann GF, Penzien J, Ruiter JPN, Wanders RJA, Mayatepek E (2001) Hum Genet 108:404-408

175. Van Hove JL, Grünewald S, Jaeken J, Demaerel P, Declercq PE, Bourdoux P, Niezen-Koning K, Deanfeld JE, Leonard JV (2003) Lancet 361:1433-1435

176. Wolf B (1991) J Inherit Metab Dis 14:923-927

177. Zaffanello M, Zamboni G, Schadewaldt P, Borgiani P, Novelli G (2005) Genet Med 7:211-212

178. Farrell PM, Kosorok MR, Laxova A, Shen G, Koscik RE, Bruns WT, Splaingard M, Mischler EH (1997) N Engl J Med 337:963-969

179. Ranieri E, Lewis BD, Gerace RL, Ryall RG, Morris CP, Nelson PV, Carey WF, Robertson EF (1994) BMJ 308:1469-1472

180. UK Newborn Screening Program Centre (2005) http://www.ich.ucl. ac.uk/newborn/download/national_std_protocol_algorithm.pdf

181. Wilcken B, Wiley V, Sherry G, Bayliss $U^{-}$(1995) J Pediatr 127:965-970

182. Comeau AM, Parad RB, Dorkin HL, Dovey M, Gerstle R, Haver K, Lapey A, O'Sullivan BP, Waltz DA, Zwerdling RG, Eaton RB (2004) Pediatrics 113:1573-1581

183. Modell B, Darlison M (2008) Bull World Health Org 06-036673

184. Schulze A, Frommhold D, Hoffmann GF, Mayatepek E (2001) Clin Chem 47:1424-1429

185. Al-Dirbashi OY, Rashed MS, Brink HJ, Jakobs C, Filimban N, AlAhaidib LY, Jacob M, Al-Sayed MM, Al-Hassnan Z, Faqeih E (2006) J Chromatogr B Anal Technol Biomed Life Sci 831:274-280

186. Deodato F, Boenzi S, Santorelli FM, Dionisi-Vici C (2006) Am J Med Genet C Semin Med Genet 142:104-112
187. Fowler B (1998) Eur J Pediatr 157(Suppl 2):S60-S66

188. Frazier DM, Millington DS, McCandless SE, Koeberl DD, Weavil SD, Chaing SH, Muenzer J (2006) J Inherit Metab Dis 29:76-85

189. Gibson KM, Bennett MJ, Naylor EW, Morton DH (1998) J Pediatr 132:519-523

190. Dantas MF, Suormala T, Randolph A, Coelho D, Fowler B, Valle D, Baumgartner MR (2005) Hum Mutat 26:164

191. Arnold GL, Koeberl DD, Matern D, Barshop B, Braverman N, Burton B, Cederbaum S, Feigenbaum A, Garganta C, Gibson J, Goodman SI, Harding C, Kahler S, Kronn D, Longo N (2008) Mol Genet Metab 93:363-370

192. Häberle J, Pauli S, Schmidt E, Schulze-Eilfing B, Berning C, Koch HG (2003) Mol Genet Metab 80:302-306

193. Bodamer OA, Bloesch SM, Gregg AR, Stockler-Ipsiroglu S, O'Brien WE (2001) Clin Chim Acta 308:173-178

194. Stöckler S, Hanefeld F, Frahm J (1996) Lancet 348:789-790

195. La Marca G, Malvagia S, Pasquini E, Donati MA, Gasperini S, Procopio E, Zammarcki E (2005) Rapid Commun Mass Spectrom 19:863-864

196. Hiyama E, Iehara T, Sugimoto T, Fukuzawa M, Hayashi Y, Sasaki F, Sugiyama M, Kondo S, Yoneda A, Yamaoka H, Tjiri T, Akazawa K, Ohtaki M (2008) Lancet 371:1173-1180

197. Wald NJ, Law M (2001) J Med Screen 8:58-59

198. Liebl B, Nennstiel-Ratzel U, von Kries R, Fingerhut R, Olgemöller B, Zapf A, Roscher AA (2002) Prev Med 34:127-131

199. Smith R (2002) BMJ 324:883-885

200. Nennstiel-Ratzel U, Arenz S, Maier EM, Knerr I, Baumkötter J, Röschinger W, Liebl B, Hadorn HB, Roscher AA, von Kries R (2005) Mol Genet Metab 55:157-159

201. Andresen BS, Dobrowolski SF, O'Reilly L, Muenzer J, McCandless SE, Frazier DM, Udvari S, Bross P, Knudsen I, Banas R, Chace DH, Engel P, Naylor EW, Gregersen N (2001) Am J Hum Genet 68:1408-1418

202. Vijay S, Patterson A, Olpin S, Henderson MJ, Clark S, Day C, Savill G, Walter JH (2006) J Inherit Metab Dis 29:627-630

203. Widhalm K, Virmani K (1994) Pediatrics 94:861-866

204. Holtzman C, Slazyk WE, Cordero JF, Hannon WH (1986) Pediatrics 78:553-558

205. Liebl B, Nennstiel-Ratzel U, von Kries R, Fingerhut R, Olgemöller B, Zapf A, Roscher AA (2002) Prev Med 34:132-137 